\title{
Development of Well-Porous Structured Leavened Food Product from Rice-based Composite Flour
}

\author{
H.A. Rathnayake ${ }^{1}$, S.B. Navaratne ${ }^{1^{*}}$ and C.M. Navaratne ${ }^{2}$ \\ ${ }^{1}$ Department of Food Science and Technology, University of Sri Jayewardenepura, \\ Nugegoda, Sri Lanka \\ ${ }^{2}$ Department of Agricultural Engineering, University of Ruhuna, Kamburupitiya, Sri Lanka
}

Date Received: 09-03-2021

Date Accepted: 12-04-2021

\begin{abstract}
Well-porous structured leavened food products with a proper texture have a high demand in the dynamic food market. Hence, the current study was focused to formulate a leavened food product with a proper porous and better-textured crumb using rice-based composite flour $(\mathrm{CF})$. Nine CF samples were prepared according to Taguchi's orthogonal array by taking three variables (corn flour, finger millet flour, green gram flour) at three levels $(0,5 \%, 10 \%)$. Nine dough samples were prepared from each CF sample and subjected to fermentation and gelatinization under $1 \mathrm{~kg} / \mathrm{cm}^{2}$ initial air pressure condition. Results revealed that crumb sample prepared from CF4 (Rice: Wheat: Corn: Green gram, 50:40:5:5) showed higher crumb volume, specific volume, lower bulk density and better crumb cellular structure properties which did not significantly different ( $\mathrm{p}>0.05)$ to $\mathrm{CF} 1$ (Rice: Wheat, 50:50). Further, CF4 imparted to have the lowest crumb hardness, gumminess and chewiness. Thus, CF4 was selected as the best CF sample, which yielded a leavened food product with better textural and structural properties.
\end{abstract}

Keywords: composite flour, fermentation, porous-crumb structure, rice flour, Taguchi's orthogonal array

\section{Introduction}

Due to the increasing lifestyle diseases and nutritional concern, demand for the novel and healthy foods are increasing (Patil et al., 2016). Thus, the application of composite flour in developing leavenedbaked food products using alternative flours to wheat flour has gained a huge interest in the global food industry (Menon et al., 2015). The term "composite flour" is defined by Seibel (2011) as "a mixture of flours from tubers rich in starch and/or flours rich in protein and/or cereals, with or without incorporating wheat flour". Generally, rice, corn, sorghum, finger millet, buckwheat are the frequently applied grains in substituting wheat flour for the development of leavened-baked products. Among them, rice flour is highly consumed due to its hypoallergenic properties, low sodium content, pale appearance, and trivial flavour (Mancebo et al., 2015; Wu et al., 2019). Further, Rice (Oryza sativa L.) is the staple food of more than half of the world population and is the second most-consumed cereal in the world (Cho et al., 2019).

Corn (Zea mays L.), is one of the most commonly consumed cereal crops throughout the world and it contributes to produce over billion tons of yield annually throughout the globe (Sun et al., 2019). Corn is a highly nutritious cereal crop, is rich in dietary fibre, vitamins, minerals, essential amino acids along with functional elements such as phenolics, flavonoids, anthocyanin, $\beta$-carotene, and lutein (Zhang et al., 2016; Julianti et al., 2017; Sun et al., 2019). Finger millet (Eleusine coracana L.) is a nutritious small-seeded coarse cereal that contains a considerable amount of protein (with essential amino

*Correspondence: sbnava@sci.sjp.ac.lk

Tel: +94 775095610

(C) University of Sri Jayewardenepura 
acids), dietary fibre, minerals (especially calcium, iron, phosphorus), and vitamin (including pro-vitamin A and vitamin B) (Devani et al., 2016; Patil et al., 2016; Thorat and Ramachandran, 2016). Due to the higher phenolic content in finger millet grains, it has a cholesterol-lowering capability along with the ability to regulate blood glucose homeostasis. Hence, finger millet flour is a commonly applied constituent in composite flour mixes as a functional food ingredient in developing a variety of food products including soup mixes, noodles, pasta products, and bakery products, particularly bread and biscuit (Devani et al., 2016; Patil et al., 2016). Green gram (Vigna radiate) is a protein-rich legume and is known as one of the cheapest and the richest sources of plant protein (Pasha et al., 2011). Further, Green gram contains essential fatty acids, vitamins (B1 and B2), minerals (Phosphorous, Calcium, Iron), and antioxidant properties (Pasha et al., 2011; Rajiv et al., 2012; Shukla et al., 2016).

However, little work has been reported in the literature regarding the evaluation of functional flour properties and porous crumb structural properties of leavened food products prepared from composite flour out of rice flour, wheat flour, corn flour, finger millet flour, and green gram flour. Under this circumstance, the current study was conducted with a view to expanding the utilization of rice flour, corn flour, finger millet flour, and green gram flour in developing leavened food products. Thus, composite flour samples were prepared according to Taguchi's orthogonal array while using rice flour as the major ingredient (50\%) along with the other grain flours. Crumb samples were prepared out of composite flour samples and fermentation and gelatinisation of them were carried out under slightly high initial air pressure condition. Prepared crumb samples were subjected to evaluate textural and structural properties; in order to select the best composite flour sample.

\section{Materials and Methods}

\subsection{Materials}

Certified paddy was obtained from Rice Research and Development Institute Bathalegoda, Sri Lanka. Corn, Finger millet, Green gram, and other major ingredients for crumb sample preparation such as wheat flour, bakers' yeast, salt, sugar, and shortening were purchased from local reputed supermarkets in Colombo, Sri Lanka.

\subsection{Preparation of rice flour}

Paddy was cleaned, de-husked and polished. Thereafter, polished rice grains were cleaned and subjected to heat-moisture treatment as per the method described by Navaratne (2015). The treated rice grains were soaked in cold water $\left(25 \pm 2^{\circ} \mathrm{C}\right)$ for 4 hours followed by grinding (National, MX-110PN, Japan). The ground rice flour was dried (Leader-GPME350SSVISS080, UK) at $55 \pm 1^{\circ} \mathrm{C}$ for 4 hours and sieved using $180 \mu \mathrm{m}$ sieve (Endecotts@, Minor 200, United Kingdom).

\subsection{Preparation of corn flour}

Corn grains were cleaned and soaked in $0.5 \%$ SMS solution $\left(25 \pm 2^{\circ} \mathrm{C}\right)$ for 8 hours. The wellsoaked grains were washed thoroughly with pure water and placed in a freezer at $-17 \pm 2^{\circ} \mathrm{C}$ (Hisense $\subset$, FC-40DD4SA, China) for 8 hours. The frozen grains were soaked again in water $\left(25 \pm 2^{\circ} \mathrm{C}\right)$ for 8 hours followed by freezing for another 8 hours. Finally, the grains were thawed and ground (National@, MX$110 \mathrm{PN}$, Japan). The ground corn flour was dried (Leader-GPME350SSVISS080@, UK) at $55 \pm 1^{\circ} \mathrm{C}$ for 6 hours and sieved using the $180 \mu \mathrm{m}$ sieve.

\subsection{Preparation of finger millet flour}

Finger millet grains were cleaned and soaked in water at $25 \pm 2^{\circ} \mathrm{C}$ for 6 hours followed by drying at $60 \pm 5^{\circ} \mathrm{C}$ for 4 hours using a rotary dryer. Well-dried grains were ground with a disintegrator (Biobase, HSD-80, China) and passed through the $180 \mu \mathrm{m}$ sieve. 


\subsection{Preparation of green gram flour}

Green gram grains were cleaned and soaked in water at $25 \pm 2^{\circ} \mathrm{C}$ for 3 hours followed by drying at $60 \pm 5^{\circ} \mathrm{C}$ for 8 hours using a rotary dryer. Well-dried grains were ground (Bio-base $\odot$, HSD-80, China) and passed through the $180 \mu \mathrm{m}$ sieve.

\subsection{Preparation of composite flour according to Taguchi's orthogonal array}

Nine rice-based composite flour samples were prepared according to the statistical design of Taguchi's orthogonal array (L9 design) using three variables namely corn flour, finger millet flour, and green gram flour at three levels $(0 \%, 5 \%, 10 \%$; for $100 \mathrm{~g}$ flour basis) as given in Table 1 .

Table 1: Nine composite flour samples according to Taguchi's orthogonal array (L9 design).

\begin{tabular}{lccccc}
\hline $\begin{array}{l}\text { Abbreviation of } \\
\text { Composite flour } \\
\text { samples }\end{array}$ & $\begin{array}{c}\text { Rice flour } \\
(\%)\end{array}$ & $\begin{array}{c}\text { Wheat flour } \\
(\%)\end{array}$ & $\begin{array}{c}\text { Corn } \\
\text { flour }(\%)\end{array}$ & $\begin{array}{c}\text { Finger Millet } \\
\text { flour }(\%)\end{array}$ & $\begin{array}{c}\text { Green gram } \\
\text { flour }(\%)\end{array}$ \\
\hline CF1 & 50 & 50 & 0 & 0 & 0 \\
CF2 & 50 & 40 & 0 & 5 & 5 \\
CF3 & 50 & 30 & 0 & 10 & 10 \\
CF5 & 50 & 40 & 5 & 0 & 5 \\
CF5 & 50 & 30 & 5 & 5 & 10 \\
CF6 & 50 & 35 & 5 & 10 & 0 \\
CF7 & 50 & 30 & 10 & 0 & 10 \\
CF8 & 50 & 35 & 10 & 5 & 0 \\
CF9 & 50 & 25 & 10 & 10 & 5 \\
\hline
\end{tabular}

\subsection{Preparation of crumb samples}

Gelatinised crumb samples were prepared using the nine CF samples by performing the fermentation and gelatinisation at a slightly high air pressure condition $\left(1 \mathrm{~kg} / \mathrm{cm}^{2}\right.$ initial air pressure $)$ according to the method described by Rathnayake et al. (2019).

\subsection{Evaluation of functional flour properties of nine $C F$ samples}

Water absorption capacity (WAC) and oil absorption capacity (OAC) of the nine CF samples were determined according to the method described by Chandra et al. (2015) with slight modifications. Therein, approximately $1.00 \pm 0.002 \mathrm{~g}$ (Axis analytical balance, ALN220, Poland) of each CF was dispersed in $10.00 \mathrm{~mL}$ distilled water (for WAC) and refined vegetable oil (for OAC) at $28 \pm 2^{\circ} \mathrm{C}$ for 30 minutes. Thereafter, the paste was centrifuged (Hermle labortechnik gmbh $\odot$, Universal Centrifuge, $\mathrm{Z}$ 306, Germany) at 3,000 rpm for 10 minutes and the supernatant was weighed. WAC was calculated as grams of water bound per one gram of $\mathrm{CF}$. OAC was calculated as grams of oil bound per gram of CF.

\subsection{Evaluation of crumb physical properties}

(a) Volume, specific volume and bulk density

Gelatinised crumb samples were cooled at room temperature $\left(29 \pm 2^{\circ} \mathrm{C}, 69 \% \mathrm{RH}\right)$ for 25 minutes. Thereafter, volume $\left(\mathrm{cm}^{3}\right)$, specific volume $\left(\mathrm{cm}^{3} / \mathrm{g}\right)$, and bulk density $\left(\mathrm{g} / \mathrm{cm}^{3}\right)$ of the crumb samples were evaluated following the seed displacement method (AACC International, 2000; Aplevicz et al., 2013).

\section{(b) Texture profile analysis}

Texture profiles of the nine crumb samples were analysed using CT3 texture profile analyser concerning $20.00 \pm 1 \mathrm{~mm}$ sample height, $25 \mathrm{~mm}$ diameter probe (TA11/1,000), two compression cycles, $50 \%$ penetration depth, $5 \mathrm{~g}$ trigger load, $1 \mathrm{~mm} / \mathrm{s}$ test speed, and 4,500 g load cell. Thereafter, Hardness 
(g), Springiness (mm), Cohesiveness, Gumminess (g), and Chewiness $(\mathrm{mJ})$ of the crumb samples were assessed using Brookfield Texture ProCT Software TA-CT-PAD-AY.

(c) Crumb cellular structure properties (Image analysis)

Approximately, $3.00 \pm 0.5 \mathrm{~mm}$ thick slices of the nine crumb samples (30 slices from each) were scanned (flatbed scanner, Canon Lide-120) under the resolution of 300 dpi and saved in JPEG format. Porosity (\%), Cell density (number of cells per unit area $\mathrm{cm}^{2}$ ), Average cell area $\left(\mathrm{cm}^{2}\right)$, Cell circularity, Solidity, and Fractal dimension (following box-counting method) of the scanned images were evaluated using ImageJ software following the steps described by Pérez-Nieto et al. (2010).

\subsection{Statistical analysis}

The data obtained from the study were statistically analysed (at 95\% confidence level) according to one-way ANOVA (followed by Tukey sample comparison) using Minitab 17 statistical software. All the samples and treatments were replicated thrice and the relevant graphs were drawn using Microsoft Excel 2013.

\section{Results and Discussion}

\subsection{Functional flour properties of nine CF samples}

Flour hydration properties namely water absorption capacity (WAC) and oil absorption capacity (OAC) of the nine composite flour samples are given in plot "A" and plot "B" respectively of Figure 1.

WAC is an important functional property for baking applications as well as for bulking and consistency of a final product (Amandikwa et al., 2015). According to plot "A" in Figure 1, WAC of CF1 (rice flour: wheat flour, 50:50 ratio) is the lowest, and the addition of different proportions of corn, finger millet, and green gram flours to the rice and wheat flour mix considerably affected to the WAC of the flour samples. However, WAC values of CF2, CF4, CF6, CF7, and CF8 are not significantly different ( $>0.05$ ) to the WAC of CF1. Oladunmoye et al. (2010) and Chandra and Samsher (2013) have also observed that the WAC of wheat flour is lower than that of rice flour, corn flour, and green gram flour. Hallén et al. (2004) have also stated that if the flour sample contained a higher percentage of protein, the WAC of the flour mix is getting higher. Because, protein can absorb water up to $200 \%$ of its weight while carbohydrates can absorb water only up to $15 \%$ of its weight (Akubor and Ukwuru, 2003). As per the results shown in plot "A" in Figure 1, composite flour samples of CF3, CF5, and CF9 have high WAC values, and these values are significantly higher $(\mathrm{p}<0.05)$ than that of CF1. This is maybe due to the higher percentage (10\%) of green gram flour in CF3 and CF5 and the lower percentage of wheat flour $(25 \%)$ in CF9.

Fat and oils contribute to getting a product with a softer texture and more acceptable flavour. Hence, OAC is an important functional property that improves the mouth feel and the flavour retention of the final product (Amandikwa et al., 2015; Iwe et al., 2016; Julianti et al., 2017). According to plot "B" in Figure 1, CF4 shows the lowest OAC among the nine composite flour samples. However, the OAC value of CF4 is significantly different $(p<0.05)$ to the same value of $C F 7$, and the OAC values of the other composite flour samples are not significantly different $(\mathrm{p}>0.05)$ to the OAC value of CF4. Results of the flour hydration properties depict in Figure 1 further demonstrate that all the composite flour samples exhibit a stronger affinity for oil rather than water.

\subsection{Crumb physical properties}

Volume, specific volume and bulk density, texture profile analysis, and cellular structure properties of the crumb samples prepared from nine composite flour samples are depicted in Table 2, 3, and 4 respectively. Figure 2 represents the scanned images (300 dpi) of the cross-sections of crumb samples. 
According to the results given in Table 2, CF4 sample imparted to have a higher crumb volume, specific volume, and a lower bulk density compared to the other crumb samples that contained corn, finger millet, and green gram flours.
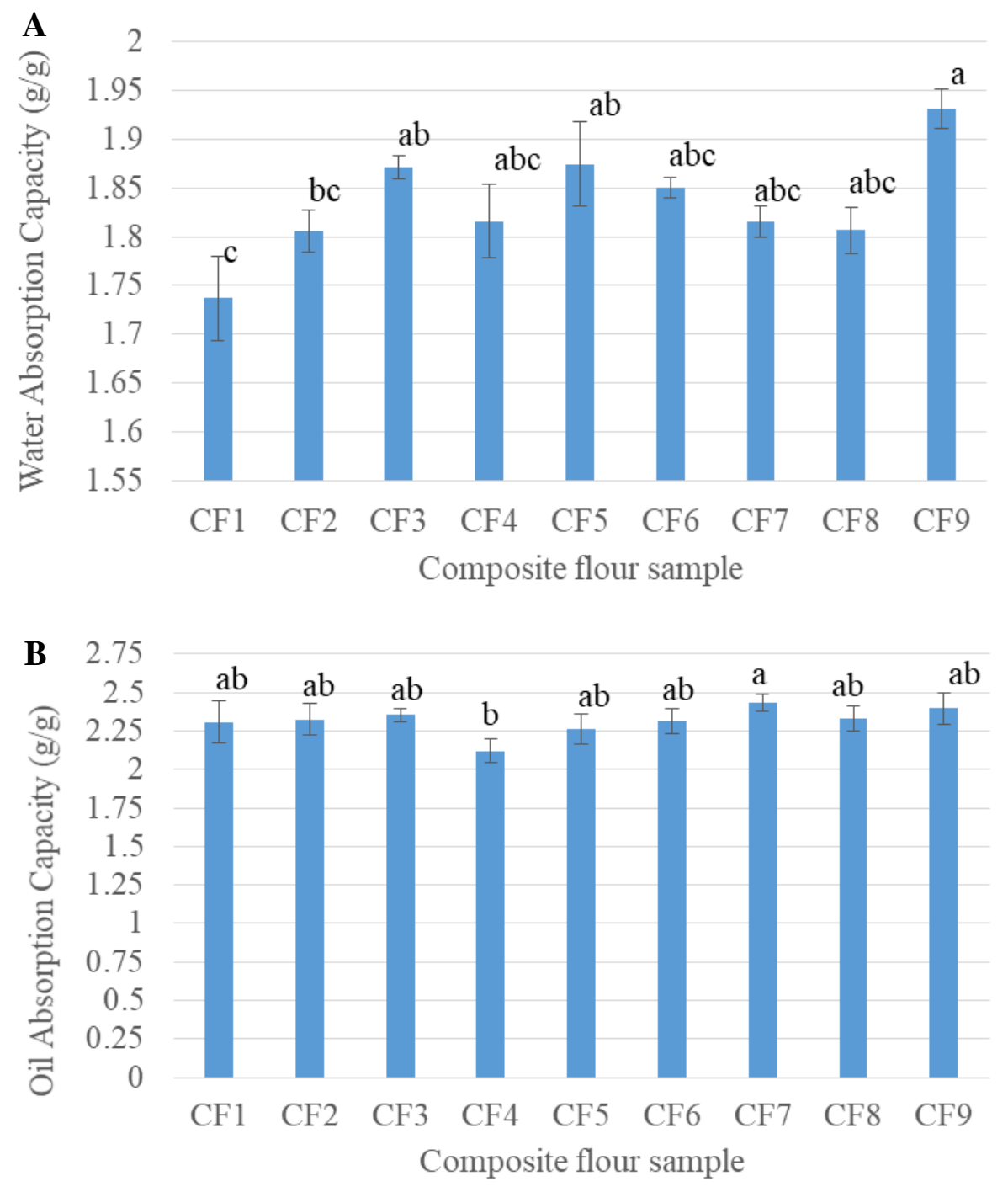

Figure 1: Hydration properties of composite flour samples; (A) Water absorption capacity, (B) Oil absorption capacity. (Bar values are represented as mean $\pm \mathrm{SD}$ of replicates; mean values in the same plot with different superscripts are significantly different at 0.05 significant level).

Amandikwa et al. (2015) have stated that if higher the WAC of a flour sample, the weight of the final product gets increased, resulting to have a lower specific volume. According to the current study, CF9 and CF3 samples demonstrated the highest $(1.931 \pm 0.020 \mathrm{~g} / \mathrm{g})$ and the second-highest $(1.878 \pm 0.011$ $\mathrm{g} / \mathrm{g})$ WAC values respectively. So also, as per the results given in Table 2, the crumb sample prepared from CF9 has the lowest crumb volume, specific volume, and the highest bulk density compared to the other eight crumb samples. Moreover, the crumb sample prepared from CF3 also shows lower crumb specific volume and higher bulk density values, however; these values are not significantly different ( $p>0.05$ ) to the same parameters of the crumb sample prepared from CF9. 
Table 2: Volume, specific volume, and bulk density of crumb samples prepared from the nine composite flour samples.

\begin{tabular}{|c|c|c|c|}
\hline $\begin{array}{l}\text { Composite } \\
\text { flour }\end{array}$ & $\begin{array}{l}\text { Crumb volume } \\
\left(\mathrm{cm}^{3}\right)\end{array}$ & $\begin{array}{l}\text { Specific volume } \\
\left(\mathrm{cm}^{3} / \mathrm{g}\right)\end{array}$ & $\begin{array}{l}\text { Bulk density } \\
\left(\mathrm{g} / \mathrm{cm}^{3}\right)\end{array}$ \\
\hline $\mathrm{CF} 1$ & $60.459 \pm 0.541^{\mathrm{a}}$ & $2.162 \pm 0.028^{\mathrm{a}}$ & $0.463 \pm 0.006^{\mathrm{f}}$ \\
\hline $\mathrm{CF} 2$ & $53.540 \pm 1.269^{\mathrm{bc}}$ & $1.908 \pm 0.062^{\mathrm{bcd}}$ & $0.525 \pm 0.017^{\text {cde }}$ \\
\hline CF3 & $48.607 \pm 0.470^{\mathrm{e}}$ & $1.735 \pm 0.021^{\mathrm{ef}}$ & $0.576 \pm 0.007^{\mathrm{ab}}$ \\
\hline CF4 & $55.740 \pm 1.730^{\mathrm{b}}$ & $2.010 \pm 0.119^{\mathrm{ab}}$ & $0.499 \pm 0.019^{\mathrm{ef}}$ \\
\hline CF5 & $49.793 \pm 1.362^{\mathrm{de}}$ & $1.775 \pm 0.055^{\text {cdef }}$ & $0.563 \pm 0.018^{\mathrm{bc}}$ \\
\hline CF6 & $48.828 \pm 0.585^{\mathrm{e}}$ & $1.754 \pm 0.040^{\mathrm{def}}$ & $0.570 \pm 0.013^{\mathrm{bc}}$ \\
\hline CF7 & $50.544 \pm 0.328^{\text {cde }}$ & $1.809 \pm 0.025^{\mathrm{cde}}$ & $0.553 \pm 0.002^{\mathrm{bcd}}$ \\
\hline CF8 & $53.190 \pm 1.910^{\mathrm{bcd}}$ & $1.945 \pm 0.065^{\mathrm{bc}}$ & $0.515 \pm 0.017^{\mathrm{de}}$ \\
\hline CF9 & $43.857 \pm 1.442^{\mathrm{f}}$ & $1.613 \pm 0.061^{\mathrm{f}}$ & $0.621 \pm 0.013^{\mathrm{a}}$ \\
\hline
\end{tabular}

*Results are represented as mean \pm SD of replicates; mean values in the same column with different superscripts are significantly different at 0.05 significant level.

Texture Profile Analysis (TPA) is an imitative test that is similar to what goes within the human mouth (Rosenthal, 1999) and it is an important parameter for evaluating the effect of different CF on developing a textured product. When following the instrumental texture profile analysis, texture profile attributes are calculated based on the compression curve of force versus time plot, where, peak force of the first compression cycle represents the hardness $(\mathrm{g})$ of the product. The density that continues throughout the chewing is considered as the gumminess $(\mathrm{g})$ and the energy required to chew the sample to make it ready for swallowing (depending on the gumminess and springiness) is referred to as the chewiness (mJ) (Patil et al., 2016; Rathnayake et al., 2018).

Table 3: Texture profile analysis of crumb samples prepared from the nine composite flour samples.

\begin{tabular}{lccccc}
\hline $\begin{array}{l}\text { Composite } \\
\text { flour } \\
\text { samples }\end{array}$ & Hardness $(\mathrm{g})$ & $\begin{array}{c}\text { Springiness } \\
(\mathrm{mm})\end{array}$ & Cohesiveness & Gumminess $(\mathrm{g})$ & Chewiness $(\mathrm{mJ})$ \\
\hline CF1 & $1305.000 \pm 104.600^{\mathrm{e}}$ & $9.767 \pm 0.299^{\mathrm{bcd}}$ & $0.570 \pm 0.037^{\mathrm{a}}$ & $740.200 \pm 44.000^{\mathrm{de}}$ & $70.640 \pm 3.560^{\mathrm{c}}$ \\
CF2 & $1901.700 \pm 206.900^{\text {cd }}$ & $9.373 \pm 0.168^{\mathrm{d}}$ & $0.530 \pm 0.013^{\mathrm{b}}$ & $1132.800 \pm 69.400^{\mathrm{c}}$ & $104.000 \pm 7.040^{\mathrm{b}}$ \\
CF3 & $2962.000 \pm 165.000^{\mathrm{ab}}$ & $9.370 \pm 0.119^{\mathrm{d}}$ & $0.475 \pm 0.017^{\mathrm{e}}$ & $1629.700 \pm 108.800^{\mathrm{a}}$ & $140.220 \pm 14.010$ \\
CF4 & $1299.200 \pm 151.400^{\mathrm{e}}$ & $10.009 \pm 0.176^{\mathrm{ab}}$ & $0.537 \pm 0.018^{\mathrm{b}}$ & $643.700 \pm 32.600^{\mathrm{e}}$ & $82.460 \pm 7.770^{\mathrm{bc}}$ \\
CF5 & $2137.600 \pm 101.100^{\mathrm{c}}$ & $9.637 \pm 0.231^{\mathrm{bcd}}$ & $0.485 \pm 0.017^{\mathrm{de}}$ & $1025.600 \pm 100.500^{\mathrm{c}}$ & $96.890 \pm 18.760^{\mathrm{b}}$ \\
CF6 & $1798.000 \pm 99.600^{\mathrm{d}}$ & $9.425 \pm 0.268^{\mathrm{cd}}$ & $0.590 \pm 0.008^{\mathrm{a}}$ & $1036.660 \pm 24.990^{\mathrm{c}}$ & $95.860 \pm 5.840^{\mathrm{bc}}$ \\
CF7 & $2747.000 \pm 191.800^{\mathrm{b}}$ & $9.875 \pm 0.202^{\mathrm{b}}$ & $0.507 \pm 0.010^{\mathrm{bcd}}$ & $1431.500 \pm 53.700^{\mathrm{b}}$ & $138.000 \pm 3.690^{\mathrm{a}}$ \\
CF8 & $1695.900 \pm 127.600^{\mathrm{d}}$ & $10.357 \pm 0.248^{\mathrm{a}}$ & $0.519 \pm 0.011^{\mathrm{bc}}$ & $835.400 \pm 31.600^{\mathrm{c}}$ & $95.100 \pm 13.300^{\mathrm{b}}$ \\
CF9 & $3205.000 \pm 210.800^{\mathrm{a}}$ & $9.814 \pm 0.107^{\mathrm{bc}}$ & $0.490 \pm 0.016^{\text {cde }}$ & $1580.100 \pm 49.100^{\mathrm{a}}$ & $157.260 \pm 18.240$ \\
\hline
\end{tabular}

*Results are represented as mean \pm SD of replicates; mean values in the same column with different superscripts are significantly different at 0.05 significant level.

According to the results of TPA given in Table 3, the crumb sample prepared from CF4 shows better crumb textural properties with the lowest crumb hardness, gumminess, and chewiness values compared to all the other crumb samples which contained corn, finger millet, and green gram flour. Since, the crumb samples prepared from CF4 and CF8 having the highest springiness values, these two samples indicate a comparatively higher ability of recoverability after withdrawing the compressive force.

Saha et al. (2011) have observed, with the reduction of wheat flour percentage of a composite flour sample, the cohesiveness of the crumb samples getting lower due to the reduced gluten plasticity. The results of the current study (Table 3 ) are also in agreement with that observation, because composite 
flour samples namely CF3, CF5, CF7, and CF9 having comparatively lower percentages of wheat flour than the other composite flour samples. Hence, these samples contributed to develop crumbs with lower cohesiveness values.

According to the digital image analysis, a well-developed porous crumb structure can be identified by high porosity along with a finer and a regular gas cell structure (Lassoued et al., 2008). Cell density is an indication of a finer crumb cellular structure and it can be evaluated by the total number of cells detected over a total measured area (Che Pa et al., 2013).

Even though the crumb samples prepared from CF3 and CF9 having the highest cell density, these two samples show significantly low $(\mathrm{p}<0.05)$ porosity, average cell area, cell circularity, solidity, and significantly high $(\mathrm{p}<0.05)$ fractal dimension $(\mathrm{FD})$ compared to the crumb sample prepared from CF1 (Table 4). Further, according to Figure 2, crumb samples prepared from CF3 and CF9 having a poorly developed porous crumb structure. The lowest crumb volume, specific volume, the highest bulk density (Table 2) and the highest crumb hardness, gumminess, and chewiness (Table 3) were obtained from these two samples and also prove that crumb samples prepared from these two samples (CF3 and CF9) having a lower gas retention capacity along with poor porous-crumb structural properties.

Cell circularity that is ranging from 0 to 1 (line to a perfect circle) is a shape factor for analysing the shape of a gas cell (Crowley et al., 2000). Crumb solidity is considered as the ratio between the area of the crumb sample and the convex area. The crumb samples prepared from CF1 and CF4 having the highest cell circularity and solidity values and these values are not significantly different $(p>0.05)$ from each other. Further, porosity, cell density, and the average cell area of the crumb sample prepared from CF4 are also not significantly different $(\mathrm{p}>0.05)$ from the same values of the crumb sample prepared from CF1. Moreover, the crumb sample prepared from CF4 has the second-lowest FD value compared to the rest of the eight crumb samples. Thus, these observations indicate that the crumb sample prepared from CF4 sample contributed to develop simpler and smoother grey-level images with more circular and solid gas cells.

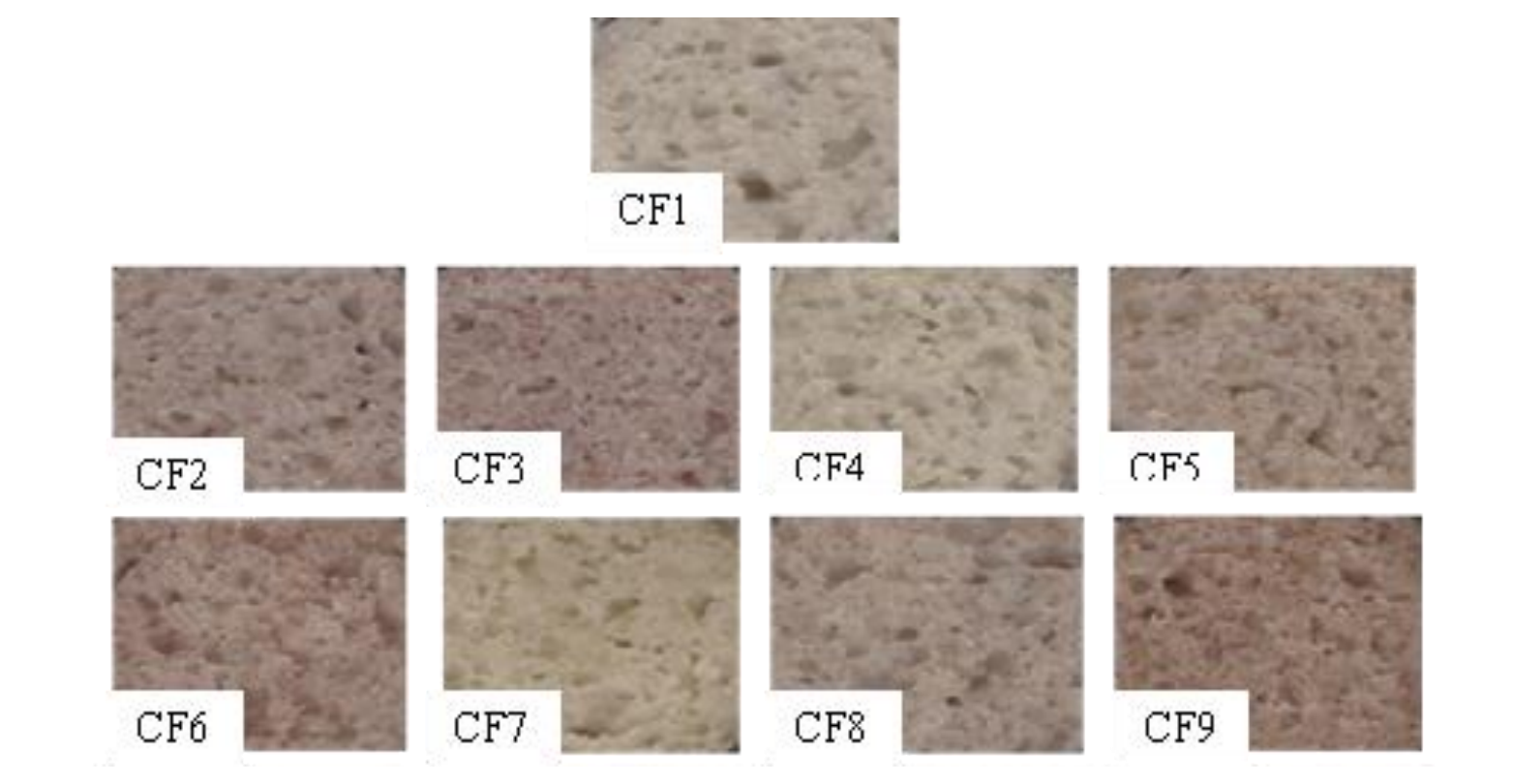

Figure 2. Scanned images of the crumb samples prepared from the nine composite flour samples. 
Table 4: Cellular structure properties (Image analysis) of the crumb samples prepared from nine composite flour samples.

\begin{tabular}{|c|c|c|c|c|c|c|}
\hline $\begin{array}{l}\text { Composite } \\
\text { flour } \\
\text { samples }\end{array}$ & $\begin{array}{l}\text { Cell density } \\
\left(\text { cell } / \mathrm{cm}^{2}\right)\end{array}$ & $\begin{array}{l}\text { Porosity } \\
(\%)\end{array}$ & $\begin{array}{l}\text { Average cell } \\
\text { area }\left(\mathrm{cm}^{2}\right)\end{array}$ & $\begin{array}{c}\text { Cell } \\
\text { circularity }\end{array}$ & Solidity & $\begin{array}{c}\text { Fractal } \\
\text { dimension }\end{array}$ \\
\hline CF1 & $24.486 \pm 1.017^{\mathrm{f}}$ & $30.791 \pm 1.991^{\mathrm{bc}}$ & $0.013 \pm 0.002^{\mathrm{ab}}$ & $0.506 \pm 0.020^{\mathrm{ab}}$ & $0.730 \pm 0.021^{\mathrm{a}}$ & $1.659 \pm 0.031^{\mathrm{c}}$ \\
\hline $\mathrm{CF} 2$ & $30.797 \pm 2.319^{\mathrm{cd}}$ & $30.244 \pm 1.554^{\mathrm{cd}}$ & $0.010 \pm 0.001^{\mathrm{cd}}$ & $0.474 \pm 0.020^{c}$ & $0.689 \pm 0.011^{\mathrm{cd}}$ & $1.696 \pm 0.030^{\mathrm{ab}}$ \\
\hline CF3 & $38.507 \pm 2.623^{\mathrm{a}}$ & $28.375 \pm 1.940^{\mathrm{de}}$ & $0.007 \pm 0.001^{\mathrm{d}}$ & $0.444 \pm 0.023^{\mathrm{d}}$ & $0.670 \pm 0.013^{\mathrm{d}}$ & $1.710 \pm 0.023^{\mathrm{ab}}$ \\
\hline CF4 & $26.576 \pm 2.176^{\mathrm{ef}}$ & $31.846 \pm 2.011^{\mathrm{abc}}$ & $0.012 \pm 0.002^{b c}$ & $0.512 \pm 0.015^{\mathrm{a}}$ & $0.726 \pm 0.013^{\mathrm{a}}$ & $1.689 \pm 0.019^{b}$ \\
\hline CF5 & $28.102 \pm 3.048^{\mathrm{e}}$ & $32.888 \pm 3.062^{\mathrm{a}}$ & $0.012 \pm 0.002^{\mathrm{bc}}$ & $0.464 \pm 0.020^{\mathrm{cd}}$ & $0.686 \pm 0.018^{\mathrm{cd}}$ & $1.714 \pm 0.015^{\mathrm{ab}}$ \\
\hline CF6 & $33.023 \pm 2.601^{b c}$ & $32.948 \pm 2.152^{\mathrm{abc}}$ & $0.010 \pm 0.002^{\mathrm{cd}}$ & $0.446 \pm 0.017^{\mathrm{d}}$ & $0.674 \pm 0.013^{\mathrm{d}}$ & $1.722 \pm 0.022^{\mathrm{a}}$ \\
\hline CF7 & $25.409 \pm 1.309^{\mathrm{f}}$ & $33.607 \pm 1.492^{\mathrm{a}}$ & $0.015 \pm 0.002^{\mathrm{a}}$ & $0.487 \pm 0.022^{b c}$ & $0.713 \pm 0.016^{\mathrm{ab}}$ & $1.700 \pm 0.022^{\mathrm{ab}}$ \\
\hline CF8 & $28.330 \pm 2.436^{\mathrm{de}}$ & $32.610 \pm 2.457^{\mathrm{abc}}$ & $0.012 \pm 0.002^{b c}$ & $0.479 \pm 0.028^{c}$ & $0.701 \pm 0.020^{\mathrm{bc}}$ & $1.712 \pm 0.027^{\mathrm{ab}}$ \\
\hline CF9 & $35.398 \pm 2.229^{b}$ & $27.740 \pm 2.462^{\mathrm{e}}$ & $0.008 \pm 0.001^{\mathrm{d}}$ & $0.464 \pm 0.017^{\mathrm{cd}}$ & $0.681 \pm 0.010^{\mathrm{d}}$ & $1.705 \pm 0.029^{\mathrm{ab}}$ \\
\hline
\end{tabular}

*Results are represented as mean \pm SD of replicates; mean values in the same column with different superscripts are significantly different at 0.05 significant level.

\section{Conclusion}

Different CF mixtures would differently affect on the flour functional properties and the development of well-porous structured leavened food products with better crumb textural and structural properties. All the composite flour samples exhibited a stronger affinity for oil rather than water. CF4 (Rice: wheat: corn: green gram flours with the ratio of 50:40:5:5) was selected as the best flour combination as this flour mixture imparted to develop a leavened food product with a higher gas retention capacity and better crumb textural and cellular structural properties.

\section{Acknowledgment}

Research Council, University of Sri Jayewardenepura, Sri Lanka for funding the project [Grant number: ASP/01/RE/SCI/2019/12] and the Department of Food Science and Technology, University of Sri Jayewardenepura, Sri Lanka for providing laboratory facilities.

\section{References}

AACC International, 2000. Standard 10-05.Approved Methods of American Association of Cereal Chemists, (10th ed). The Association: St. Paul, MN.

Akubor, P.I. and Ukwuru, M.U., 2003. Functional properties and biscuit making potential of soybean and cassava flour blends. Plant foods for human nutrition, 58:1-12.

Amandikwa, C., Iwe, M.O., Uzomah, A. and Olawuni, A.I., 2015. Physico-chemical properties of wheatyam flour composite bread. Nigerian Food Journal, 33:12-17.

Aplevicz, K.S., Ogliari, P.J. and Sant'Anna, E.S., 2013. Influence of fermentation time on characteristics of sourdough bread. Brazilian Journal of Pharmaceutical Sciences, 49:233-239.

Chandra, S. and Samsher, 2013. Assessment of functional properties of different flours. African Journal of Agricultural Research, 8:4849-4852.

Chandra, S., Singh, S. and Kumari, D., 2015. Evaluation of functional properties of composite flours and sensorial attributes of composite flour biscuits. Journal of Food Science and Technology, 52:3681-3688.

Cho, S.H., Lee, B.H. and Eun, J.B., 2019. Physicochemical properties of dry- and semi-wet-milled rice flours after fermentation by Lactobacillus amylovorus. Journal of Cereal Science, 85:15-19.

Crowley, P., Grau, H. and Arendt, E.K., 2000. Influence of additives and mixing time on crumb grain characteristics of wheat bread. Cereal Chemistry, 77:370-375. 
Devani, B.M., Jani, B.L., Kapopara, M.B., Vyas, D.M. and Ningthoujam, M.D., 2016. Study on quality of white bread enriched with finger millet flour. International Journal of Agriculture, Environment and Biotechnology, 9:903-907.

Hallén, E., Ibanoğlu, Ş. and Ainsworth, P., 2004. Effect of fermented/germinated cowpea flour addition on the rheological and baking properties of wheat flour. Journal of Food Engineering, 63:177184.

Iwe, M.O., Onyeukwu, U. and Agiriga, A.N., 2016. Proximate, functional and pasting properties of FARO 44 rice, African yam bean and brown cowpea seeds composite flour. Cogent Food \& Agriculture, 2:1142409.

Julianti, E., Rusmarilin, H. and Yusraini, E., 2017. Functional and rheological properties of composite flour from sweet potato, maize, soybean and xanthan gum. Journal of the Saudi Society of Agricultural Sciences, 16:171-177.

Lassoued, N., Babin, P., Della Valle, G., Devaux, M.F. and Réguerre, A.L., 2008. Baked product texture: correlations between instrumental and sensory characterization using Flash Profile. Journal of Cereal Science, 48:133-143.

Mancebo, C.M., Merino, C., Martínez, M.M. and Gómez, M., 2015. Mixture design of rice flour, maize starch and wheat starch for optimization of gluten free bread quality. Journal of Food Science and Technology, 52:6323-6333.

Menon, L., Majumdar, S.D. and Ravi, U., 2015. Development and analysis of composite flour bread. Journal of food science and technology, 52:4156-65.

Navaratne, S.B., 2015. Manual Technology of rice bread making. University of Sri Jayewardenepura.

Oladunmoye, O.O., Akinoso, R. and Olapade, A.A., 2010. Evaluation of some physical-chemical properties of Wheat, Cassava, Maize and Cowpea flours for bread making. Journal of Food Quality, 33:693-708.

Pasha, I., Rashid, S., Anjum, F.M., Sultan, M.T., Qayyum, M.N. and Saeed, F., 2011. Quality evaluation of wheat-mungbean flour blends and their utilization in baked products. Pakistan Joural of Nutrition, 10:388-392.

Patil, S.S., Rudra, S.G., Varghese, E. and Kaur, C., 2016. Effect of extruded finger millet (Eleusine coracan L.) on textural properties and sensory acceptability of composite bread. Food Bioscience, 14:62-69.

Pérez-Nieto, A., Chanona-Pérez, J.J., Farrera-Rebollo, R.R., Gutiérrez-López, G.F., Alamilla-Beltrán, L. and Calderón-Domínguez, G., 2010. Image analysis of structural changes in dough during baking. LWT. Food Science and Technology, 43:535-543.

Rajiv, J., Soumya, C., Indrani, D. and Venkateswara Rao, G., 2012. Influence of green gram flour (phaseolus aureus) on the rehology, microstructure and quality of cookies. Journal of Texture Studies, 43:350-360.

Rathnayake, H.A., Navaratne, S.B. and Navaratne, C.M., 2018. Porous crumb structure of leavened baked products. International Journal of Food Science, Volume2018:15 pages.

Rathnayake, H.A., Navaratne, S. and Navaratne, C., 2019. Improving porous crumb structure of ricerelated leavened food products by fermentation and gelatinization at slightly higher air pressure conditions. Journal of Texture Studies, 50:564-570.

Rosenthal, A. 1999. Relation between instrumental and sensory measures of food texture. Food Texture: Measurement and Perception,1-17.

Saha, S., Gupta, A., Singh, S.R.K., Bharti, N., Singh, K.P., Mahajan, V. and Gupta, H.S., 2011. Compositional and varietal influence of finger millet flour on rheological properties of dough and quality of biscuit. LWT. Food Science and Technology, 44:616-621.

Seibel, W., 2011. 16 Composite flours. Future of Flour, 193-198. www.muehlenchemie.de/ downloadsfuture-of-flours/fof_kap_16.pdf. Accessed 21 August 2017. 
Shukla, R.N., Mishra, A.A. and Gautam, A.K., 2016. Development of protein enriched biscuit fortified with green gram flour. Food Science Research Journal, 7:112-118.

Sun, H., Ju, Q., Ma, J., Chen, J., Li, Y., Yuan, Y., Hu, Y., Fujita, K. and Luan, G., 2019. The effects of extruded corn flour on rheological properties of wheat-based composite dough and the bread quality. Food Science and Nutrition, 7:2977-2985.

Thorat, S.S. and Ramachandran, P., 2016. Effect of finger millet flour on rheological properties of wheat dough for the preparation of bread. International Journal of Food and Nutritional Science, 5:7481 .

Wu, T., Wang, L., Li, Y., Qian, H., Liu, L., Tong, L. and Zhou, X., 2019. Effect of milling methods on the properties of rice flour and gluten-free rice bread. LWT. Food Science and Technology, 108:137-144.

Zhang, X., Chen, Y., Zhang, R., Zhang, Y., Luo, Y., Xu, S., Liu, J., Xue, J. and Guo, D., 2016. Effects of extrusion treatment on physicochemical properties and in vitro digestion of pregelatinized high amylose maize flour. Journal of Cereal Science, 68:108-115. 